No letter should be more than 400 words.

For letters on scientific subjects we normally reserve our correspondence columns for those relating to issues discussed recently (within six weeks) in the B.MJ.

We do not routinely acknowledge letters. Please send a stamped addressed envelope if you would like an acknowledgment.

Because we receive many more letters than we can publish we may shorten those we do print, particularly when we receive several on the same subject.

\section{Cardiopulmonary resuscitation and the MRCGP examination}

SIR,-After lengthy debate it has now been decided that the basic skills of cardiopulmonary resuscitation should become a mandatory requirement for entrance to the examination for membership of the Royal College of General Practitioners. On the face of it this should be welcomed as, indeed, such skills are so basic and essential that the safety of the public demands that every practising doctor should be well versed with the technique.

There are, however, also certain anxieties which demand consideration. For instance, every British medical school has a responsibility for teaching basic cardiopulmonary resuscitation and British doctors should have acquired such skills by the time of qualification. Furthermore, during the preregistration year one of the first essential skills that has to be reinforced and practised is cardiopulmonary resuscitation. Therefore it does seem rather odd that a postgraduate medical examination which cannot be taken for at least four years after graduation suddenly requires a certificate of competence in this particular skill. This sets a dangerous precedent for other facets of knowledge and skill which traditionally have been considered to be part and parcel of undergraduate medical education and accordingly assessed at medical school. Indeed, this casts a shadow over the validity of the basic medical qualification.

The other aspect of the new requirement which we find embarrassing is the fact that a general practitioner's competence has to be examined by ambulancemen. We hold ambulancemen in high regard; they do an excellent job, under poorly paid and often very difficult conditions. But that qualified doctors should go to ambulancemen to be tested in cardiopulmonary resuscitation does sound strange. If, despite the above argument, there is still a lingering doubt about the teaching of resuscitation in undergraduate and preregistration periods and it is felt strongly that this should be tackled at postgraduate level, surely the most appropriate place for learning such a skill is the accident and emergency department. There are now over 200 consultants in accident and emergency medicine and 60 senior registrars across Britain. Cardiopulmonary resuscitation is one of the major features of their daily work. It would be far more appropriate for a consultant in accident and emergency to test a general practitioner's competence and sign the appropriate certificate than a local ambulanceman. It is entirely inappropriate for professional men who have had five years of university undergraduate medical education, a year's preregistration training in medicine, and surgery, and often six months or more in an accident and emergency department, to go to an ambulance centre to be tested by someone of far less educational standing, training, and experience.

D H WILSON

Postgraduate Dean's Office,

JAMIE BAHRAMI

Faculty of Medicine,

University of Leeds,

Leeds

\section{Oestrogen deficiency and oestradiol implants}

SIR, - In answer to Mr Kevin F Gangar and others ${ }^{1}$ the physiological effects of oestradiol on the skeleton do not diminish with continued treatment and increasing doses are not required to maintain skeletal integrity. ${ }^{23}$ The problem with oestradiol implants, however, is not that the hormone becomes increasingly ineffective but that flushes occur in response to a relative decline in hormone concentrations. We therefore stand by our statement $^{4}$ that this is a withdrawal phenomenon, not tachyphylaxis.

The question remains how to treat women with implants who flush when oestradiol concentration is still considerably increased. Mr Gangar and others not surprisingly find transdermal oestradiol of limited value and fail to understand why vaginal oestriol might help.' If only they had read the discussion section of our article they would have appreciated that unlike vaginal conjugated equine oestrogens $^{6}$ the effects of vaginal oestriol are sustained despite long term use. Furthermore, although we do not know how the various compounds used to treat flushing achieve their effect, there is no reason to assume that the mechanism is the same in each case. Indeed, in our studies of vascular effects of different compounds used to treat the climacteric, including oestradiol and oestriol, individual and disparate effects on the peripheral vasculature have been found despite a common clinical action. ${ }^{78}$ All the more reason, therefore, to try a different substance when oestradiol fails to control symptoms.

It is also fallacious to equate oestradiol implants with pregnancy. Women may receive menopausal treatment for many years; pregnancy lasts for only 280 days. Moreover, pregnancy is a unique state associated with altered patterns of steroid and peptide hormones and changed immunological activity. The two conditions are clearly different, and we should be wary of citing high oestradiol concentrations in pregnancy as evidence for long term safety of oestradiol implants.

JEAN GINSBERG P HARDIMAN

\section{Royal Frec Hospital,}

London NW'3 $20 \mathrm{OG}$

1 Gangar K, Cust MP, Whitehead MI. Oestrogen deficiency and westradiol implants. Br Med f 1989;299:1279-80. (18 November.
2 Christiansen C, Christiansen MS, McNair P, Hagen C, Stockland K-E, Transbol IB. Prevention of early postmenopausal bone loss: controlled two vear study in 315 normal females. Fiur f C lin $\operatorname{In} x \cdot s t 1989 ; 10 \cdot 273-9$

3 Sarvas M, Studd JWW, Fogelman 1, Montgomery J, Murbr B. Skelc al effects of oral oestrogens compared with subcutancous oestrogen nd testosterone in postmenopausal women. $\mathrm{Br}$. Hed f 1988;297:331-3.

+ Ginsburg J, Hardiman P. Oestrogen deficiency and oestradio implants. Br Med f 1989;299:1031

5 Fink RS, Collins WP, Papadiki L, O'Reilly B, Ginsburg J. Vaginal oestriol: effective menopausal therapy not associated with endometrial hyperplasia. Fournal of Gynaecology and Endocrinology 1985;1:1-11.

6 Dyer GI, Young O, Townsend PT, colins WP, Whitehead MI. Dose-related changes in vaginal cytology after topical conjugated equine oestrogens. BrMed f 1982;284:789.

7 Ginsburg J, Hardiman P. The peripheral circulation in the insburg J, Hardiman P. The peripheral circulation in the menopause. In: Ginsburg J, ed. The circulation in the femalefrom the cradle to the grave. Carnforth, England: Parthenon,
1989: 99-115.

8 Ginsburg J, Hardiman P. Cardiovascular effects of transdermal estradiol in postmenopausal women. Ann NY Acad Sci in press).

SIR, - The recent correspondence from Mr Studd and coworkers' contains various errors, mostly of attribution or interpretation, which require correction.

We studied postmenopausal women receiving oestradiol implants to relieve menopausal symptoms and reported three observations ${ }^{2}$ : firstly, that implants can result in supraphysiological concentrations of oestradiol (above $1200 \mathrm{pmol} / \mathrm{l}$, the periovulatory peak); secondly, that symptoms of oestrogen deficiency recur in the presence of these abnormally high concentrations; and, thirdly, that in some women the duration of relief of symptoms becomes progressively shorter with subsequent implantation. Eight of our 12 patients eventually derived benefit for durations ranging from only three to nine weeks after the last implantation.

$\mathrm{Mr}$ Studd and coworkers accuse us of plagiarism by stating that our "observations are not new," and they cite four references to their own work as justification. ${ }^{3-6}$ Having read and reread these papers we reject their criticism. Cardozo et al reported that symptoms returned when the plasma oestradiol values "fell from moderately high levels to normal." The oestradiol concentrations that they observed ranged from 484 to $951 \mathrm{pmol} / 1$ (stated normal premenopausal range $90-1050 \mathrm{pmol} / \mathrm{l}$ ). Indeed, they commented that "levels of oestrone and oestradiol showed little evidence of accumulation and did not exceed the normal, premenopausal range." Savvas et al reported that "the [median] serum oestradiol concentration in the implant group was $725 \mathrm{pmol} / \mathrm{l}$." The range was 372 $2370 \mathrm{pmol} / \mathrm{l}$, but the fact that some patients had developed abnormally high values was not commented upon at all. Brincat et al showed benefits from implants in a placebo controlled study. They did not present data on plasma oestradiol. In their review article Studd and Magos applied a different interpretation to the results of Cardozo et $a l^{3}$ and commented that "the 